\title{
PENGARUH CAR, NPL, DAN ROA TERHADAP PENYALURAN KREDIT USAHA RAKYAT (Studi Kasus pada PT Bank Rakyat Indonesia Tbk)
}

\author{
Suci Prihartini ${ }^{1}$ \\ I Made Dana ${ }^{2}$ \\ ${ }^{1,2}$ Fakultas Ekonomi dan Bisnis Universitas Udayana (Unud), Bali - Indonesia \\ email: suciprihartini10@gmail.com
}

\begin{abstract}
ABSTRAK
Bank Rakyat Indonesia telah memberikan kontribusi positif dalam pengembangan UMKM di Indonesia dengan program Kredit Usaha Rakyat (KUR). Faktor internal yang mempengaruhi penyaluran KUR yaitu Capital Adequacy Ratio (CAR), Non Performing Loan (NPL), dan Return On Assets (ROA), sehingga penelitian ini bertujuan untuk mengetahui pengaruh CAR dan NPL terhadap penyaluran KUR dengan ROA sebagai mediasi. Penelitian ini menggunakan pendekatan kuantitatif merupakan studi kasus di Bank Rakyat Indonesia tahun 2009-2016. Metode pengumppulan data yaitu observasi non pasrtisipan dengan mengakses website www.bri.co.id dan menggunakan teknik analisis jalur dengan model substruktur. Hasil pengujian pada sub-struktur I mengidentifikasikan bahwa CAR dan NPL berpengaruh signifikan terhadap ROA hasi hasil sub-struktur II mengidentifikasikan bahwa CAR, NPL, dan ROA berpengaruh signifikan terhadap penyaluran KUR. Hasil uji sobel mengidentifikasikan bahwa ada pengaruh tidak langsung antara CAR dan NPL terhadap penyaluran KUR dengan ROA sebagai mediasi.
\end{abstract}

Kata Kunci: Capital Adequacy Ratio (CAR), Kredit Usaha Rakyat (KUR), Non Performing Loan (NPL), Return On Assets (ROA)

\begin{abstract}
Bank Rakyat Indonesia has made a positive contribution in the development of SMEs in Indonesia with the Kredit Usaha Rakyat (KUR) program. Internal factors affecting the distribution of KUR, that is Capital Adequacy Ratio (CAR), Non Performing Loan(NPL), and Return On Assets (ROA), so this study aims to determine the effect of CAR, NPL on distribution of KUR with ROA as mediation. This research used the quantitative approach and case study at Bank Rakyat Indonesia 2009-2016. Data collection methode is nonparticipant observation by accessing website www.bri.co.id and used path analysis techniques with sub-structure model. Sub-structure I indicate that CAR, NPL significant effect on ROA and sub-structure II indicate that CAR, NPL, ROA have significant effect on the distribution of KUR. Sobel test indicate there is an indirect effect between CAR and NPL on distribution of KUR with ROA as mediation.
\end{abstract}

Keyword: Capital Adequacy Ratio (CAR), Kredit Usaha Rakyat (KUR), Non Performing Loan (NPL), Return On Assets (ROA) 


\section{PENDAHULUAN}

Peran utama keberadaan UMKM di Indonesia sangat penting yaitu sebagai salah satu penggerak prtumbuhan ekonomi Indonesia serta upaya untuk mengatasi masalah kemiskinan, pengangguran, dan pemerataan pendapatan. Aktivitas UMKM ternyata masih menghadapi banyak masalah, salah satunya adalah masalah permodalan yang merupakan faktor kritis bagi UMKM, masalah ini masih sulit dicarikan solusinya oleh para ahli di negeri ini (Kusuma, 2014).

Bank Rakyat Indonesia merupakan bank yang melayani kebutuhan modal bagi pelaku UMKM dan telah memberikan kontribusi positif dalam pengembangan UMKM di Indonesia dnegan program Kredit Usaha Rakyat (KUR). KUR adalah jenis pinjaman dari pemerintah untuk pelaku UMKM yang merupakan salah satu kebijakan pemerintah yang dijalankan melalui bank dalam upaya meningkatkan perekonomian negara (Dudin, 2017). KUR mempunyai manfaat yang cukup bedar bago perekonomian rakyat dan bagi bisnis perbankan. Menurut Leksana (2016) keuntungan yang diperoleh pedagang bias meningkat setelah mendapatkan pemberian KUR.

Penyaluran KUR Bank Rakyat Indonesa dari tahun 2009 sampai 2016 terus mengalami fluktuasi kzrena factor intenal maupun factor eksternal. Penyaluran kredit membantu masyarakat dalam melakukan aktivitas seperti investasi, konsumsi, serta distribusi. Semua aktivitas tersebut berhubungn dengan penggunaan uang yang juga merupakan kegiatan pembangunan perekonomian masyarakat. 


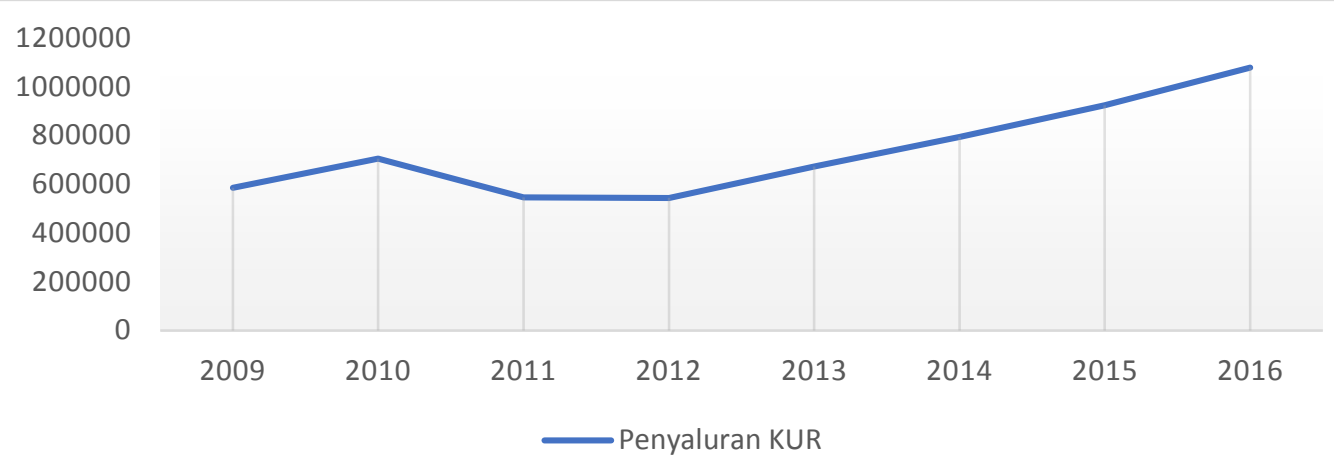

\section{Gambar 1. Grafik Fluktuasi Penyaluran KUR pada PT Bank Rakyat Indonesia Tbk} Sumber: www.bri.co.id

Berdasarkan Gambar 1, terlihat bahwa penyaluran KUR mengalami peningkatan pada tahun 2010 sebesar 20,6\% dan tahun 2011 sampai 2012 mengalami penurunan karena pada tahun 2011 terjadi krisis perekonomian global dan persaingan di antara pelaku industri perbankan dalam memperebutkan potensi bisnis konsmer nasional. Penurunan penyaluran KUR pada tahun 2011 adalah sebesar $22,50 \%$ sedangkan penurunan pada tahun 2012 hanya sebesar $0,44 \%$ dari tahun sebelumnya, penurunan pada tahun 2012 karena belum membaiknya kondisi perekonomian global hingga akhir tahun 2012. Pada tahun 2-13 sampai tahun 2016, terlihat bahwa penyaluran KUR terus mengalami penigkatan yang cukup bak (www.bri.co.id). Berdasarkan fenomena tersebut terdapat beberapa faktor yang diduga dapat mempengaruhi penyaluran KUR.

Faktor yang berpengaruh terhadap penyaluran KUR adalah Capital Adequacy Ratio (CAR), karena CAR merupakan rasio permodalan yang digunakan untuk menunjukan kemampuan menyediakan dana untuk menampung risiko atas kerugian dari kegiatan operasional dan untuk mengembangkan usaha (Prabowo, 2014). Semakin tinggi risiko, maka risk marginnya juga tinggi, hal ini akan 
menurunkan tingkat pendapatan sehingga mempengaruhi jumlah kredit yang disalurkan (Andreani \& Marya, 2013).

Faktor kedua yang mempengaruhi penyaluran KUR adalah Non Performing Loan (NPL) yang merupakan rasio kredit bermasalah yang dapat diketahui dengan membandingkat total kredit bermasalah dengan tolal kredit. Tingginya NPL membuat bank harus menanggung tingginya risiko kredit bermasalah, sehingga penyaluran kredit akan turun karena dipengaruhi oleh tingkat kesehatan suatu bank (Andreani \& Marya, 2013).

Variabel Return On Assets (ROA) dijadikan variabel mediasi dlam penelitian ini karena dirasa mampu memperjelas hubungan antara CAR dan NPL terhadap penyaluran KUR. Selain itu, ROA merupakan rasio untuk mengukur laba pada kinerja bank dalam mengelola penghimpunan dananya. Tingginya pengembalian atas aset oleh bank, akan meningkatkan perolehan laba sehingga penyaluran kredit UMKM juga akan meningkat, karena posisi bank yang memiliki tingkat kinerja yang cukup baik (Kusnandar, 2012).

Berdasarkan latar belakang yang telah di uraikan sebelumnya, maka didapat rumusan masalah dalam penelitian ini adalah: 1) Bagaimanakah pengaruh CAR terhadap ROA? 2) Bagaimanakah pengaruh NPL terhadap ROA? 3) Bagaimanakah pengaruh CAR terhadap penyaluran KUR? 4) Bagaimanakah pengaruh NPL terhadap penyaluran KUR? 5) Bagimanakah pengaruh ROA terhadap penyaluran KUR? 6) Bagaimanakah ROA mampu memediasi pengaruh CAR terhadap penyaluran KUR? 7) Bagaimanakah ROA mampu memediasi pengaruh CAR terhadap penyaluran KUR?. Berdasarkan rumusan masalah tersebut, maka tujuan 
dari penelitian ini adalah: 1) Untuk mengetahui pengaruh CAR terhadap ROA. 2) Untuk mengetahui pengaruh NPL terhadap ROA. 3) untuk mengetahui pengaruh CAR terhadap penyaluran KUR. 4) Untuk mengetahui pengaruh NPL terhadap penyaluran KUR. 5) Untuk mengetahui pengaruh ROA terhadap penyaluran KUR. 6) Untuk mengetahui apakah ROA mampu memediasi pengaruh CAR terhadap penyaluran KUR. 7) Untuk mengetahui apakah ROA mampu memediasi pengaruh NPL terhadap penyaluran KUR.

Adapun kegunaan teoritis yang didapatkan dari penelitian ini yaitu diharapkan mampu menjadi bukti empiris serta sumber referensi untuk penelitian selanjutnya mengenai penyaluran KUR. Kegunaan praktis dalam penelitian in yaitu diharapkan dapat memberikan informasi dan bahan pertimbangan bagi perusahaan khususnya PT Bank Rakyat Indonesa Tbk dala menetapkan kebijakan-kebijakan dimasa mendatang mengenai faktor yang mempengaruhi penyaluran KUR.

CAR merupakan indikator kemampuan ban untuk menyediakan dana bagi ekspansi dan menerima risk loss yang disebabkan olh operasi bank (Buchory, 2014). Penerapan strategi manajemen oleh bank, menunjukan bahwa CAR menentukan bantalan yang tersedua bagi bank terhadap risiko kredit, risiko operasional dan kenaikan pasar (Bhatia et al., 2012). Bank dengan rasio CAR yang tinggi akan mampu melindungi bank dari risiko, sehingga kinerja bank akan meningkat seperti peningkatan profitabilitas dan berakibat pada penurunan ROA bank. Bank yang memiliki modal yang tinggi maka keuntungan yang diperoleh juga akan tinggi karena bank lebih cermat dalam memilih sumber pembiyaannya, 
sehingga hal ini berrati apabila rasio CAR meningkat maka akan diikuti oleh peningkatan pasa rasio ROA (Al-Qudah \& Mahmoud, 2013).

Gizaw et al. (2015). Arman dkk. (2015), dam Anshika (2016) mengatakan bahwa CAR berpengaruh positif terhadap ROA. Berdasarkan teori yang telah dijelaskan dan hasil penelitian sebelumnya, maka dapat diusulkan hipotesis sebagai berikut:

$\mathrm{H}_{1}$ : CAR berpengaruh positif dan signifikan terhadap ROA.

NPL adalah rasio kredit bermasalah dengan membandingkan total kredit bermaslah dengan total kredit. Tingginya NPL akan mengurangi modal pada bank, karena pendapatannya digunakan untuk mengcover tingginya NPL, sehingga akan diikuti oleh turunnya dana yang disalurkan pada periode berikutnya. Kondisi ini akan menghambat aktivitas bank dan juga akan menurunkan pendapatan pada bank, sehingga tingginya NPL akan membuat profitabilitas rendah (Wicaksono, 2016). Kenaikan NPL akan mengakibatkan laba menurun sehingga ROA semakin kecil, karena kenaikan kredit macet akan mengurangi pendapatan bank (Ameur \& Mhiri. 2013).

Penelitian ini didukung oleh hasil dari Ongroe \& Kusa (2013), Rini \& Sufian (2013), Kolapo et al. (2012), Bouheni et al. (2014), Gizaw et al. (2015). Alkhatib \& Harsheh (2012) dan Bhattarai (2017) yang mengatakab bahwa NPL berpengaruh 
negatif terhadap ROA. Berdasarkan teori yang telah dijelaskan dan hasil penelitian sebelumnya, maka dapat diusulkan hipotesis sebagai berikut:

$\mathrm{H}_{2}$ : NPL berpengaruh negatif signifikan terhadap ROA.

Tingginya rasio CAR pada bank mengidentifikasikan bahwa kecukupan modal pada bank tersebut tinggi, sehingga keadaan ini akan mempengaruhi salah satu aktivitas operasional pada bank yaitu dalam hal menyalurkan kredit. CAR adalah ukuran utama yang bisa digunakan di dunia untuk mencerminkan prifitabilitas bank dan CAR yang lebih tinggi membuktikan bahwa bank-bank tersebut sudah cukup banyak memastikan pinjamannya, sehingga kecukupan modal mempengaruhi jumlah kredit yang disalurkan oleh perbankan (Cai \& Zhonglin, 2014). Menurue Amalia (2014) serta Widiyanti \& Muchtar (2014) menjelaskan bahwa secara parsial CAR berpengaruh positif dan signifikan terhadap penyaluran kredit UMKM.

Berdasarkan teori yang telah dijelaskan dan hasil penelitian sebelumnya, maka dapat diusulkan hipotesis sebagai berikut:

$\mathrm{H}_{3}$ : CAR berpengaruh signifikan terhadap penyaluran KUR.

NPL digunakan untuk mengukur jumlah kredit bermaslah, NPL yang tinggi mencerminkan kredit macet yang tinggi, sehingga kondisi ini akan berpengaruh terhadap kesehatan bank dan akan menurunkan pendapatan pada bank, baik yang bersumber dari penerimaan bunga maupun penerimaan pengembalian pinjaman. Meningkatnya risiko bagi perbankan atas meningkatnya kedit bermasah membuat peputaran uang pada perbankan akan terhambat, sehingga akan menyulitkan bank dalam menyalurkan kembali dananya. Semakin tinggi NPL maka risiko yang akan 
ditanggung perbank dalam meyalurkan kredit juga akan tinggi, sehingga mempengaruhi kesehatan bank (Andreani \&Marya, 2013). Pada sistem perbankan Albania, pinjaman bermasalah adalah pinjaman yang memberikan penundaan pembayaran pokok dan bunga lebih dari 90 hari (Shingjergji \& Marsida, 2015).

Menurut Kusnandar (2012), Purba dkk. (2016), dan Sania \& Dewi (2016) menyebutkan bahwa NPL memiliki pengaruh negatif terhadap penyaluran kredit pada bank. Berdasarkan teori yang telah dijelaskan dan hasil penelitian sebelumnya, maka dapat dusulkan hipotesis sebagai berikut:

$\mathrm{H}_{4}$ : NPL berpengaruh berpengaruh negatif signifikan terhadap penyaluran KUR.

ROA merupakan rasio yang digunakan untuk mengukur kemampuan suatu bank dalam memperoleh keuntungan. Menurut Kusnandar (2012) tingginya pengembalian atas aset oleh bank, akan meningkatkan perolehan laba sehingga penyaluran kredit UMKM juga akan ikut meningkat, karena posisi bnak dalam tingkat kinerja yang cukup baik. Semakin besar laba yang dihasikan menunjukan bahwa bank sudah mengelola asetnya dengan efektif. Oleh sebab itu, persetujuan terhadap kredit yang diajukan oleh nasabah akan lebih mudah diberikan oleh bank karena bank sudah baik dalam kemampuannya menghasilkan laba, sehingga tingginya ROA makan akan meningkatkan penyaluran kredit.

Oktaviani (2012) dan Rahayu (2014) menyebutkan bahwa ROA berpengaruh positif terhadap penyaluran kredit, sehingga semakin tinggi ROA akan 
meningkatkan kredit yang disalurkan. Berdasarkan teori yang telah dijelaskan dan hasil penelitian sebelumnya, maka dapat diusulkan hiotesis sebagai berikut:

$\mathrm{H}_{5}$ : ROA berpengaruh positif dan dignifikan terhadap penyaluran KUR.

Kemampuan bank dalam mengasilkan laba dapat ditentukan oleh CAR, sehingga besarnya rasio CAR akan searah dengan besarnya rasio ROA, maka semakin tinggi ROA ditahun sebelumnya akan membuat semakin stabilnya kualitas aktiva dan manejemen labanya, hal ini akan meningkatkan penyaluran kredit di tahun berikutnya

Amalia (2014) menyatakan bahwa ada oengaruh tidak langsung variabel CAR terhadap penyaluran kredit melalui media ROA. Berdasarkan teori yang telah dijelaskan dan hasil penelitian sebelumnya, maka dapat diusulkan hipotesis sebagai berikut:

$\mathrm{H}_{6}$ : ROA memediasi pengaruh CAR terhadap penyaluran KUR.

NPL akan mengakibatkan kesempatan dalam memperoleh pendapatan atas kredit akan hilang, sehingga akan mengurangi pendapatan yang diperoleh yang tercermin melalui ROA, oleh karena itu kenaikan kredit macet akan mengurangi pendapatan bank. Saat pendapatan bank berkurang atau risiko ROA turun maka hal itu jelas akan mengurangi jumlah kredit yang diberikan kepada masyarakat dikarenakan bank berada pada posisi tingkat kinerja yang tidak cukup baik.

Amalia (2014) menyatakan bahwa ada pengaruh tidak langsung variabel NPL terhadap penyaluran KUR dengan mediasi ROA. Berdasarkan teori yang telah 
dijelaskan dan hasil penelitian sebelumnya, maka dapat diusulkan hipotesis sebagai berikut:

$\mathrm{H}_{7}$ : ROA memediasi pengaruh NPL terhadap penyaluran KUR

Berdasarkan kajian teoritis dan empiris yang telah dipaparkan sebelumnya, maka untuk memperjelas arah pada penelitian ini maka dapat dilihat kerangka konseptual sebagai berikut:

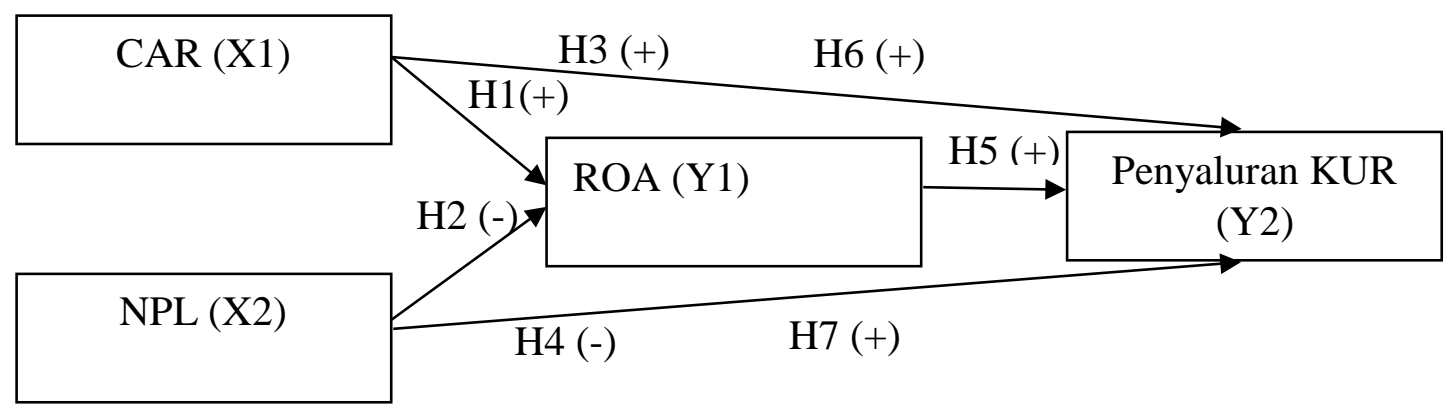

Gambar 2. Kerangka Konseptual Penelitian

Sumber: Data diolah, 2017

\section{METODE PENELITIAN}

Penelitian ini dilakukan pada PT Bank Rakyat Indonesia Tbk periode 20092016, dengan data yang didapat melalui situs resmi Bank Rakyat Indonesia yaitu www.bri.co.id. Data yang didapatkan berupa laporan keuangan triwulan perusahaan serta laporan historis lainnya. Dalam penelitian ini menggunakan jenis data kuantitatif dan kualitatif dan sumber data yang digunakan adalah data sekunder berupa laporan keuangan 2009-2016.

Penelitian ini dilakukan untuk mengetahui pengeruh CAR dan NPL terhadap penyaluran KUR dengan ROA sebagai mediasi di PT Bank Rakyat Indonesia Tbk. Peneliti menggunakan dua variabel independen/variabel bebas, satu variabel dependen/variabel terikat, dan satu variabel mediasi/intervening. Variabel 
terikat yaitu penyaluran KUR yang merupakan program dari pemerintah namun sepenuhnya dananya bersumber dari bank (www.bi.go.id). Jumlah KUR yang disalurkan Bank Rakyat Indonesia pada tahun 2009-2016 yang dinyatakan dalam jutaan rupiah. Variabel bebas yaitu CAR yang menunjukan perbandingan antara jumlah modal dengan Aset Tertimbang Menurut Risiko (ATMR) pada Bank Rakyat Indonesia tahin 2009-2016. Satuan hitung CAR pada penelitian ini adalah presentase. Rasio ini dapat diformulasikan sebagai berikut:

$$
\mathrm{CAR}=\frac{\text { Total Modal }}{\text { ATMR }} \times 100 \%
$$

Variabel bebas kedua yaitu NPL yang merupakan perbandingan antara kredit bermasalah dengan total kredit yang disalurkan pada Bank Rakyat Indonesia tahun 2009-2016. Menurut Kasmir (2010:228) rasio NPL ddihitung dengan rumu formula sebagai berikut:

$$
\mathrm{NPL}=\frac{\text { Kredit Bermasalah }}{\text { Total Kredit yang disalurkan }} \times 100 \%
$$

Variabel mediasi dalam penelitian ini adalah ROA yang merupakan perbandingan antara laba bersih dengan total asset pada Bank Rakyat Indonesia tahun 2009-2016. Menurut Sudana (2011:22), rasio ini diformulasikan sebagai berikut:

$$
\mathrm{ROA}=\frac{\text { Laba setelah pajak }}{\text { Total Aset }} \times 100 \%
$$

Penelitian ini merupakan studi kasus pada PT Bank Rakyat Indonesia Tbk. Studi kasus merupakan penelitian yang dilakukan secara terperinci terhadap lembaga dan organisasi tertentu, sehingga tidak terdapat populasi dan sampel pada penelitian ini. Studi kasus ini adalah untuk mengetahui pengaruh CAR dan NPL 
terhadap penyaluran KUR dengan ROA sebagai mediasi pada PT Bank Rakyat Indonesia tahun 2009-2016.

Metode pengumpulan data pada penelitian ini adalah metode observasi non partisipan. Perolehan data dengan metode ini yaitu dengan melakukan pengamatan dan mencatat serta mempelajari uraian dari buku, jurnal, skriso dan tesis, serta mengakses website resmi Bank Indonesia melalui ww.bi.go.id dan we resmi perusahaan melalui www.bri.co.id. Data yang diperoleh dalam bentuk laporan triwulanan.

Teknik analisis yang digunakan dalah penelitian ini adalah analisis jalur (path analysis). Analisis jalur (path analysis) merupakan perluasan analisis regresi linear berganda dalam memprediksi hubungan kausalitas (Ghozali, 2013:249). Menurut Riduwan \& Kuncoro (2011:2), analisis jalur digunakan untuk mengetahui hubungan langsung maupun tidak langsung variabel bebas terhadap variabel terikat. Pengujian hipotesis mediasi dilakukan dengan prosedur yang dikembangkan oleh Sobel (1982) yang dikenal dengan uji Sobel (Sobel Test). Uji ini dilakukan dengan cara menguji kekuatan pengaruh tidak langsung variabel bebas (X) terhadap variabel terikat (Y) melalui variabel mediasi (M). Pengujian tidak langsung X ke Y melalui $\mathrm{M}$ dihitung dengan mengalikan koefisien tidak standar $\mathrm{X} \rightarrow \mathrm{M}$ (a) dengan jalur $\mathrm{M} \rightarrow \mathrm{Y}(\mathrm{b})$ atau (ab). Standar error koefisien a dan b disimbolkan dengan $\mathrm{S}_{\mathrm{a}}$ dan $\mathrm{S}_{\mathrm{b}}$, yang dapat dihitunng dengan rumus sebagai berikut:

$$
S_{a b}=\sqrt{b^{2} S_{a}^{2}+a^{2} S_{b}^{2}}
$$

Untuk menguji signifikansi pengaruh tidak langsung, maka nilai $\mathrm{t}$ dapat dihitung dari koefisien ab yang dapat dirumuskan sebagai berikut: 


$$
\mathrm{z}=\frac{\mathrm{ab}}{\mathrm{S}_{\mathrm{ab}}}
$$

Dalam mengambil keputusanuji hipotesis dilakukan dengan cara membandingakan $p$-value dan alpha $(0,05)$ dengan ketentuan sebagai berikut:

1) Jika $p$-value $\geq$ alpha $(0,05)$ atau $\mathrm{z}$ hitung $\leq \mathrm{z}$ table, maka $\mathrm{H}_{0}$ diterima, ini berarti M bukan sebagai variabel mediasi.

2) Jika $p$-value < alpha $(0,05)$ atau $\mathrm{z}$ hitung $>\mathrm{z}$ table, maka $\mathrm{H}_{0}$ ditolak, ini berarti M sebagai variabel mediasi.

\section{HASIL DAN PEMBAHASAN}

Tabel 1.

Statistik Deskripsif Variabel CAR, NPL, ROA, dan Penyaluran KUR

\begin{tabular}{lrrrrr}
\hline \multicolumn{5}{c}{ Descriptive Statistics } \\
\hline CAR & N & Minimum & Maximum & Mean & Std. Deviation \\
NPL & 32 & 13.20 & 22.91 & 17.1881 & 2.74712 \\
ROA & 32 & 1.48 & 4.27 & 2.5416 & .85585 \\
PENYALURAN & 32 & 3.47 & 5.15 & 4.3147 & .56780 \\
KUR & 32 & 122765790 & 282558811 & 182892190.41 & 46848393.553 \\
\hline Valid N (listwise) & 32 & & & & \\
Sumber: Data diolah, 2017 & & & & &
\end{tabular}

Berdasarkan Tabel 1, maka diperoleh hasil sebagai berikut: Nilai terendah penyaluran KUR terjadi pada triwulan dua tahun 2011 dan nilai tertinggi pada triwulan empat tahun 2016 yang dapat dilihat pada Tabel 1. Rendahnya jumlah penyaluran KUR pada triwulan dua tahun 2011 dapat terjadi karena faktor internal ataupun eksternal yang menyebabkan penyaluran KUR melambat.

Nilai terendah CAR terjadi pada triwulan empat tahun 2009 yaitu sebesar 13,2 persen dan nilai tertingginya yaitu pada triwulan empat tahun 2016 sebesar 22,91 
persen. CAR yang tinggi menunjukkan bahwa modal yang disiapkan untuk mengantisipasi risiko yang mungkin terjadi relatif besar.

Nilai tererndah NPL ada triwulan satu tahun 2014 yaitu sebesar 1,48 dan nilai tertingginya pada triwulan dua tahun 2010 yaitu sebesar 4,27. Hal ini berari kredit bermasalah pada Bank Rakyat Indonesia masih tergolong aman karena belum menyentuh batas ambang yaitu lima persen.

Nilai terendah pada triwulan tiga tahun 2009 yaitu sebesar 3,47 persen dan nilai tertinggi pada triwulan empat tahun 2012 yaitu sebesar 5,15 persen. Semakin besar nilai ROA suatu bank artinya semakin besar pula tingkat keuntungan yang dicapai bank tersebut dan semakin baik pula posisi bank tersebut dari penggunaan aset.

\section{Analisi Jalur}

Penyelesaian model analisis jalur pada penelitian ini yaitu pengaruh CAR dan NPL terhadap ROA serta pengaruh CAR, NPL, dan ROA terhadap penyaluran KUR. Hasil analisis dapat dilihat pada tabel 2 dan tabel 3 berikut ini:

Tabel 2.

Regresi Struktur I

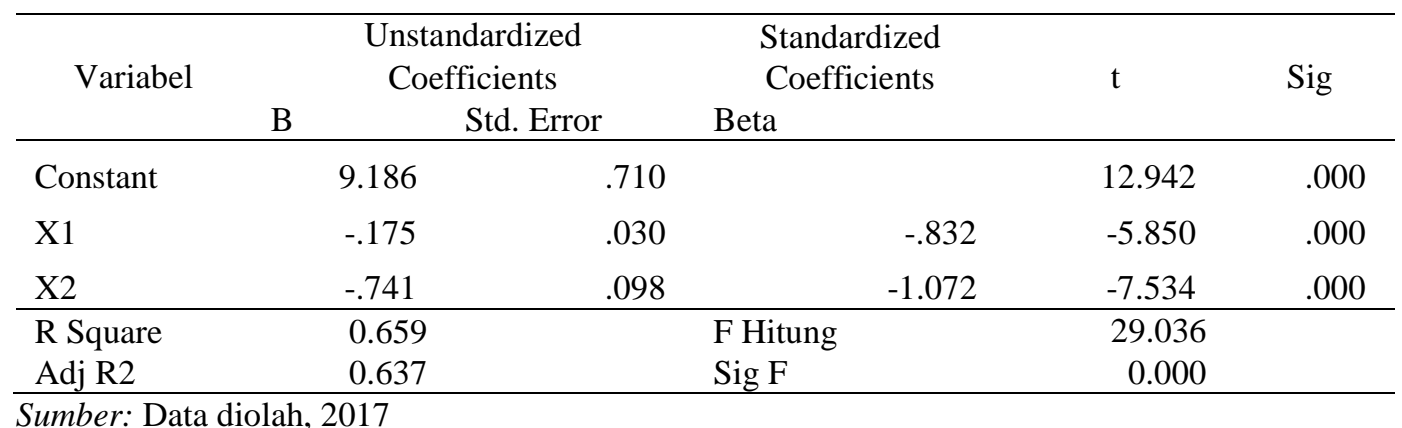


Tabel 3.

Regresi Struktur II

\begin{tabular}{|c|c|c|c|c|c|c|c|}
\hline \multirow[t]{2}{*}{ Variabel } & \multicolumn{3}{|c|}{ Unstandardized } & \multicolumn{2}{|c|}{ Standardized } & \multirow[t]{2}{*}{$\mathrm{t}$} & \multirow[t]{2}{*}{ Sig } \\
\hline & B & & Std. Error & Beta & & & \\
\hline Constant & & 19.714 & .556 & & & 35.474 & .000 \\
\hline $\mathrm{X} 1$ & & .045 & .013 & & .484 & 3.360 & .002 \\
\hline $\mathrm{X} 2$ & & -.116 & .051 & & -.381 & -2.277 & .030 \\
\hline Y1 & & -.277 & .056 & & -.628 & -4.971 & .000 \\
\hline R Square & & 0.843 & & F Hitung & & 51.717 & \\
\hline Adj R2 & & 0.826 & & Sig F & & 0.000 & \\
\hline
\end{tabular}

\section{Hasil Uji Koefisien Determinasi}

Pemeriksaan validasi model dapat dilakukan dengan menghitung koefisien determinasi total dimana hasilnya diperoleh sebagai berikut:

$$
\begin{aligned}
& \mathrm{R}^{2} m=1-\left(\mathrm{e}_{1}\right)^{2}\left(\mathrm{e}_{2}\right)^{2} \\
& \mathrm{R}^{2} m=1-(0.584)^{2}(0.396)^{2} \\
& \mathrm{R}^{2} m=1-0.0535 \\
& \mathrm{R}^{2} m=0.9465
\end{aligned}
$$

Perhitungan di atas mendapatkan hasil koefisien deterinasi total sebesar 0,9632, berarti bahwa variasi data yang dipengaruhi oleh model sebesar 94,65\% dan sisanya 5,35\% dipengaruhi oleh variabel lain diluar model.

\section{Hasil Uji Kelayakan Model}

Pengujian kelayakan model dilakukan sebelum meguji hipotesis. Jika hasil dari uji $\mathrm{F}$ adalah signifikan, maka artinya kedua variabel bebas mempengaruhi variabel terikat secara simultan dan model yang digunakan dianggap layak diuji. Pada Tabel 2 dapat dilihat nilai signifikansi uji F yaiu sebsar 0,000 yang lebih kecil dari 5\% atau 0,05, sehingga menunjukan bahwa struktur 1 , yaitu CAR dan NPL 
berpengaruh secara simultan terhadap ROA. Model ini dianggap layak uji dan pembuktian hipotesis dapat dilakukan. Pada Tabel 3 dapat dilihat nilai signifikansi uji F yaitu sebesar 0,000 yang lebih kecil dari 5\% atau 0,05, sehingga menunjukan bahwa struktur 2, yaitu CAR, NPL dan ROA berpengaruh secara simultan terhadap penyaluran KUR. Model ini dianggap layak uji dan pembuktian hipotesis dapat dilakukan.

\section{Hasil Pengujian Hipotesis}

Berdasarkan hasil analisis pengaruh CAR terhadap ROA pada tabel 2 diperoleh nilai sig. $\mathrm{t}$ sebesar 0,000 dengan nilai koefisien beta $-0,832$. Nilai Sig. $\mathrm{t}$ $0,000<0,05$ mengindikasikan bahwa $\mathrm{H}_{0}$ ditolah dan $\mathrm{H}_{1}$ diterima. Hal ini mempunya arti bahwa CAR berpengaruh negatif dan signifikan terhadap ROA.

Hasil ini tidak sesuai dengan hipoteis satu. Data pada tahun 2013 sampai dengan 2016 memperlihatkan CAR yang semakin meningkat namun ROA semakin menurun. Ini terjadi karena adanya ketidakpastian perekonomian global yaitu permintaan komoditas primer melemah dan terjadi penyesuaian harga BBM dan listrik karena porsi subsidi BBM yang meningkat. Hal ini berdampak pada pertuumbuhan perekonomian Indonesia. Sampai akhir tahun 2014 tingkat pertumbuhan ekonomi Indonesia masih melambat. Secara umum sampai dengan tahun 2015 kondisi perekonomian global masih kurang stabil devaluasi yuan dan tahun 2016 belum terlihat adanya perubahan yang signifikan dari perkembangan ekonomi Indonesia (www.bri.co.id).

Melemahnya permintaan global mengakibatkan masyarakat tidak menarik dananya dari bank dan adanya inflasi akibat lonjakan konsumsi BBM menyebabkan 
suku bunga meningkat sehingga pertumbuhan kredit menjadi lambat karena masyarakat enggan mengambil kredit sebab bunganya yang terlalu mahal. Ini mengidentifikasikan bahwa Bank Rakyat Indonesia mengalami idle fund atau dana menganggur karena banyaknya dana yang tidak disalurkan namun memiliki CAR yang relatif tinggi, yaitu rata-rata CAR pada penelitian ini mencapai 17,30\%. Tidak diimbanginya penggunaan modal dengan peninhkatan profit maka menyebabkan ROA menurun. Hasil penelitian ini didukung oleh penelitian dari Yatningsih \& Mochammad (2015) dan Sukma (2013) yang menyatakan bahwa CAR berpengaruh negative terhadap ROA.

Berdasarkan hasil analisis pengaruh NPL terhadap ROA pada tabel 2 diperoleh nilai Sig. t sebesar 0,000 dengan nilai koefisien beta -1,072. Nilai Sig. $t$ $0,000<0,05$ mengindikasikan bahwa $\mathrm{H}_{0}$ ditolak dan $\mathrm{H}_{1}$ diterima. Hal ini mempunyai arti bahwa NPL berpengaruh negatif dan signifikan terhadap ROA.

Ini berarti bahwa peningkatan rasio NPL dapat menurunkan jumlah modal pada bank, karena pendapatannya digunakan untuk mengcover NPL yang tinggi. Kondisi ini akan membuat aktivitas bank menjadi terhambat dan juga akan menurunkan pndapatan bank, sehingga semakin tinggi NPL, semakin rendah profitabilitas perbankan (Wicaksono, 2016). Dengan demikian kenaikan NPL mengakibatkan laba menurun sehingga ROA menjadi semakin kecil. Hasil penelitian ini didukung oleh hasil penelitian dari Ongore \& Kusa (2013), Rini \& Sufian (2013), Kolapo et al. (2012), Bouheni et al. (2014), Gizaw et al. (2015), Alkhatib \& Harsheh (2012) dan Bhattarai (2017) menyebutkan bahwa NPL memiliki pengaruh negatif terhadap ROA. 
Berdasarkan hasil analisis pengaruh CAR terhadap penyaluran KUR pada tabel 3 diperoleh nilai Sig. t sebesar 0,002 dengan nilai koefisien beta 0,484. Nilai Sig. t 0,002 $<0,05$ menunjukan bahwa $\mathrm{H}_{0}$ ditolak dan $\mathrm{H}_{1}$ diterima. Hal ini berrati bahwa CAR berpengaruh positif dan signifikan terhadap penyaluran KUR.

Ini berarti tingginya resentasi CAR pada bank akan membuat kinerjanya juga semakin baik karenya CAR yang tinggi menunjukan bahwa bank memiliki modal yang tinggi, sehingga akan mempengaruhi kegiatan operasional bank yaitu menyalurkan kredit UMKM (Prabowo, 2014).

Hasil penelitian ini disukung oleh hasil penelitian dari Amalia (2014) dan Widiyanti \& Muchtar (2014) yang menyatakan bahwa secara parsal CAR berpengaruh positif signifikan terhadap penyaluran kredit UMKM.

Berdasarkan hasil analisis pengaruh NPL terhadap penyaluran KUR pada tabel 3 diperoleh hasil Sig. t sebesar 0.030 dengan nilai koefisien beta $-0,381$. Nilai Sig. t 0,030<0,05 menunjukan bahwa $\mathrm{H}_{0}$ ditolah dan $\mathrm{H}_{1}$ diterima. Hal ini berarti bahwa NL berpengaruh negatif dan signifikan terhadap penyaluran KUR.

Ini berarti semakin besar NPL maka bank akan menanggung risiko kredit bermasalahnya yang tinggi sehingga kesehatan bank akan terganggu dan akan menurunkan jumlah penyaluran kredit oleh bank, dan sebaliknya (Andreani \& Marya, 2013). Hasil penelitian ini didukung oleh hasil penelitian dari Kusnandar (2012), Purba dkk. (2016), dan Sania \& Dewi (2016) yang menyatakan bahwa NPL berpengaruh negatif terhadap penyaluran kredit bank karena tingginya kredit bermasalah akan menurunkan jumlah kredit yang disalurkan. Oleh karena bank diharuskan menjaga kreditnya agar terhindar dari kredit bermasalah. 
Berdasarkan hasil analisis pengaruh ROA terhadap penyaluran KUR pada tabel 3 diperoleh nilai Sig. $t$ sebesar 0,000 dengan nilai koefisien beta -0,628. Nilai Sig. t $0,000<0,05$ mengindikasikan bahwa $\mathrm{H}_{0}$ ditolak dan $\mathrm{H}_{1}$ diterima. Hal ini berate bahwa ROA berpengaruh negative dan signifikan terhadap penyaluran KUR.

Hasil ini tidak sesuai dnegan hipotesis yang ke-lima. Data pada tahun 2010 sampai dengan 2012 memperlihatkan ROA yang semakin meningkat namun penyaluran KUR menunjukan semakin menurun. Ini terjadi karena belum kondusifnya perekonomian global karena adanya krisis keuangan berkepanjangan di kawasan Eropa dan Amerika Serikat. Kondisi ekonomi yang kurang kondusif tersebut juga telihat dari ketatnya likuiditas dan naiknya risiko kredit, khusunya kredit menengah (www.bri.co.id).

Ketatnya likuiditas menyebabkan Bank Rakyat Indonesia lebih sedikit menyalurkan dananya kepada masyarakat khusunya KUR. Kondisi in yang menyebabkan pada tahun 2010 sampai dengan 2012 penyaluran KUR terus menurun. Risiko kredit yang tinggi pada perekonomian global masih belum kondusif juga menyebabkan bank mengambil keputusan untuk tidak menyalurkan dananya. Penelitian ini memperkuat penelitian Serli (2016) yang menyatakan bahwa ROA berpengaruh negatif terhadap penyaluran kredit, yang berarti bahwa dalam menentukan volume kredit yang disalurkan bukan ROA yang sebagai dasar dalam menentukannya.

Uji sobel dalam penelitian ini digunakan untuk mengetahui pengaruh tidak langsung dari CAR (X1) terhadap penyaluran Kredit Usaha Rakyat (KUR) (Y2)

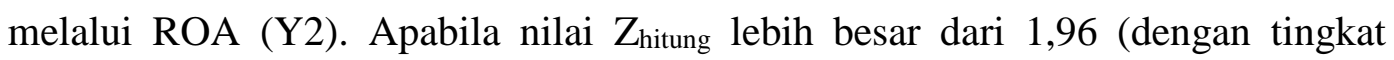


kepercayaan 95 persen), maka variabel mediator dinilai secara signifikan memediasi hubungan antara variabel bebas dengan variabel terikat. Hasil uji pengaruh CAR (X1) terhadap penyaluran Kredit Usaha Rakyat (KUR) (Y2) melalui ROA (Y1) tersaji sebagai berikut.

$$
\begin{aligned}
& Z=\frac{a b}{\sqrt{b^{2} S a^{2}+a^{2} S b^{2}+S a^{2} S b^{2}}} \\
& Z=\frac{(-0.175)(-0.277)}{\sqrt{-0.277^{2} 0.030^{2}+-0.175^{2} 0.056^{2}+0.030^{2} 0.056^{2}}} \\
& Z=3.738
\end{aligned}
$$

Hasil perhitungan uji sobel pengaruh NPL (X2) terhadap penyaluran Kredit Usaha Rakyat (KUR) (Y2) melalui ROA (Y1) tersaji sebagai berikut.

$$
\begin{aligned}
& Z=\frac{a b}{\sqrt{b^{2} S a^{2}+a^{2} S b^{2}+S a^{2} S b^{2}}} \\
& Z=\frac{(-0.741)(-0.277)}{\sqrt{-0.277^{2} 0.098^{2}+-0.741^{2} 0.056^{2}+0.098^{2} 0.056^{2}}} \\
& Z=4.114
\end{aligned}
$$

Hasil perhitungan uji sobel pengaruh CAR (X1) terhadap penyaluran Kredit Usaha Rakyat (KUR) (Y2) melalui ROA (Y1) diperoleh nilai Z Zitung sebesar 3.738 lebih besar dari 1,96 yang berarti terdapat pengaruh tidak langsung variabel eksogen terhadap variabel endogen melalui mediator. Hasil ini menunjukan bahwa ROA secara signifikan memediasi pengaruh CAR terhadap penyaluran Kredit Usaha Rakyat (KUR).

Amalia (2014) menyatakan bahwa ada pengaruh tidak langsung variabel CAR terhadap Penyaluran KUR melalui mediasi ROA. Capital Adequacy Ratio 
ditentukan oleh kemampuan bank dalam menghasilkan laba, sehingga besarnya rasio CAR akan searah dengan besarnya rasio ROA. Tingginya nilai ROA di tahun sebelumnya maka kualitas aktiva dan manajemen labanya akan semakin stabil, sehingga memungkinkan bank untuk meningkatkan jumalh kredit yang disalurkan.

Hasil perhitungan uji sobel pengaruh NPL (X2) terhadap penyaluran Kredit Usaha Rakyat (KUR) (Y2) melalui ROA (Y1) diperoleh nilai Z Zitung sebesar 4,114 lebih besar dari 1,96 yang berarti terdapat pengaruh tidak langsung variabel eksogen terhadap variabel endogen melalui mediator. Hasil ini menunjukan bahwa ROA secara signifikan memediasi pengaruh NPL terhadap penyaluran Kredit Usaha Rakyat (KUR).

Amalia (2014) menyatakan bahwa ada pengaruh tidak langsung variabel NPL terhadap Penyaluran KUR melalui mediasi ROA. NPL mengakibatkan kesempatan memperoleh pendapatan akan hilang, sehingga akan mengurangi pendapatan yang tersermin oleh ROA. Saat pendapatan bank berkurang atau rasio ROA turun maka hal itu jelas akan mengurangi jumlah kredit yang di berikan kepada masyarakat karena posisi bank dalam tingkat kinerja yang tidak cukup baik.

\section{SIMPULAN DAN SARAN}

Berdasarkan hasil analisis data dan pembahasan yang telah dijelaskan sebelumnya, maka dapat ditarik simpulan sebagai berikut: Pengaruh langsung CAR terhadap penyaluran ROA yaitu berpengaruh negatif dan signifikan. Ini berarti semakin tinggi kecukupan modal pada bank maka akan berpengaruh pada menurunnya laba perusahaan yang tercermin dari rasio Return On Assetss (ROA). 
Pengaruh langsung NPL terhadap penyaluran ROA yaitu berpengaruh negatif dan signifikan. Ini berarti semakin besar kredit bermasalah maka pendapatan yang tercermin melalui ROA juga akan berkurang.

Pengaruh langsung CAR terhadap penyaluran penyaluran KUR yaitu berpengaruh positif dan signifikan. Ini berarti kecukupan modal yang tinggi dan memadai akan meningkatkan volume kredit UMKM yang tercermin pada KUR.

Pengaruh langsung NPL terhadap penyaluran penyaluran KUR yaitu berpengaruh negatif dan signifikan. Ini berarti tingginya kredit bermasalah akan menurunkan jumlah kredit yang disalurkan.

Pengaruh langsung ROA terhadap penyaluran penyaluran Kredit Usaha Rakyat (KUR) yaitu berpengaruh negatif dan signifikan. Ini berarti kemampuan menyalurkan kredit perbankan berkurang karena bank memiliki laba yang tinggi tetapi risiko kreditnya juga tinggi.

ROA mampu memediasi pengaruh CAR terhadap penyaluran penyaluran KUR. Ini berarti kecukupan modal Bank Rakyat Indonesia yang tinggi mampu melindungi bank dari risiko yang terjadi, sehingga keinerja bank akan meningkat yang berakibat pada meningkatkannya profitabilitas sehingga mampu meningkatkan volume penyaluran KUR.

ROA mampu memediasi pengaruh NPL terhadap penyaluran penyaluran Kredit Usaha Rakyat (KUR). Ini berarti NPL akan mengakibatkan hilangnya kesempatan untuk memperoleh pendapatan dari kredit yang diberikan, sehingga pendapatan bank yang tercermin melalui ROA akan berkurang. Oleh karena itu 
kenaikan kredit macet akan mengurangi pendapatan bank. Saat pendapatan bank berkurang maka akan mengurangi jumlah penyaluran KUR.

Berdasarkan hasil penelitian dan simpulan diatas maka saran yang dapat diberikan adalah: dengan mengetahui CAR berpngaruh negatif dan signifikan terhadap ROA, sehingga diidentifikasikan bahwa Bank Rakyat Indonesia mengalami idle fund atau dana menganggur karena banyaknya dana yang tidak disalurkan namun memiliki CAR yang relatif tinggi. Maka PT Bank Rakyat Indonesia disarankan lebih mampu mengelola dana yang menganggur dengan berbagai startegi yang efektif dan sesuai.

Adanya perekonomian global yang masih belum kondusif inilah yang menyebabkan ROA berpengaruh negatif dan signifikan terhadap penyaluran KUR, sehingga dalam rangka adaptasi terhadap kondisi perekonomian global, maka pemerintah Indonesia disarankan agar mampu secara aktif melakukan berbagai upaya stabilisasi ekonomi dengan mengeluarkan beberapa Kebijakan Ekonomi.

Hasil penelitian ini diharapkan mampu memberikan informasi keada nasabah kredit khusunya KUR, karena berdasarkan hasil penelitian ini NPL atau kredit bermasalah yang timbul atas kredit macet dari nasabah berpengaruh signifikan terhadap penyaluran KUR yang mengurangi jumlah KUR yang disalurkan, oleh karena itu nasabah disarankan untuk memenuhi kewajibannya membayar kredit, sehingga Bank Rakyat Indonesia mampu meningkatkan penyaluran KUR yang bermanfaat untuk nasabah itu sendiri.

Untuk peneliti selanjutnya disarankan dapat mengembangkan penelitian dengan mengidentifikasi vaiabel lain yang dapat mempengaruhi penyaluran KUR 
seperti LDR, BOPO, DPK dan lainnya dan disarankan juga mencari menggunakan jumlah data yang lebih akurat dengan rentang waktu yang lebih panjang.

\section{REFERENSI}

Alkhatib, A., and M Harsheh. 2012. Financial Performance of Palestinian Commercial Banks. Internasional Journal of Business and Social Science, 3 (3), pp. 175-184.

Al-Qudah, Ali Mustafa., and Mahmoud Ali Jeradat. 2013. The Impact of Macroekonomic Variables and Banks Characteristics on Jordanian Oslamic bank Profitability: Empirical Evidence. International Business Research, 6 (10), pp. 153-162.

Amalia, Yuliana. 2014. Pengaruh LDR, CAR, ROA, dan NPL terhadap Penyaluran Kredit pada Bank Umum di Indonesia Periode 2008-2013. Jurnal Manajemen, 2 (3), hal. 169-186.

Ameur, I G., and Mhiri, S.M. 2013. Explanatory Factirs of Bank Performance Evidence from Tunisia. International Journal of Economics, Finance and Management, 2 (1), pp. 1-12.

Andreani dan Marya. 2013. Pengaruh Spread Tingkat Suku Bunga dan Rasio Keuangan terhadap Penyaluran Kredit UMKM pada Bank UMUM di Indonesia. Jurnal Wira Ekonomi Mikroskil, 3 (1), hal. 11-20.

Anshika. 2016. Impact of Financial Risk management on Capital Adequacy and Profitability-A Panel Study of Selected Indian commercial Banks. Splint International Journal of Professionals, 3 (3), pp. 136-147.

Arman, Moh., Wayan Cipta., dan I Wayan Suwendra. 2015. Pengaruh Kecukupan Moadal dan Tingkat penyaluran Kredit terhadap Laba pada Lembaga Perkreditan desa. E-journal Bisma Universitas Pendidikan Ganesha Jurusan Manajemen, 3 (5), hal. 1-9.

Bhatia, Aparna., Poonam Mahajan., and Subhash Chander. 2012. Determinants of Profitability of Private Sector Banks in India. Journal of Commesrce and Accounting Research, 1 (2), pp. 15-22.

Bhattarai, Yuga R. 2017. Effect of Non-Performing Loan on The Profitability of Commercial Banks in Nepal. Prestige International Journal of Management and research, 10 (2), pp. 1-9.

Bouheni, Fatem Ben., Hachmi Ben Ameur., and Abdoulkarim Idi Cheffou. 2014. The Effect of Regulation and Supervision on European Banking 
Profitability and Risk: A Panel Data Investigation. The Journal of Applied Business, 30 (6), pp. 1655-1670.

Buchory, Herry ahmad. 2014. Analysis of the Effect of Capital, Credit Risk and Profitability to Implementation Banking Intermediation Fuction (Studi on Regional Development Bank All Over Indonesia Year 2012). European Journal of Business and management, 6 (24), pp. 20-32.

Cai, Mei., and Zhonglin Huang. 2014. Analysis of Non Performing Loan and Capital Adequacy Ratio Among Chinese banks in the post-reform period in China, Journal of Advanced Studies in Finance, 5 (10), pp. 133-144.

Dudin, Mihail N. 2017. The Study Of Bank Nagari Credit Template, Indonesia. Journal of Internet Banking and Commerce, 22 (7), pp. 1-30.

Ghozali, Imam. 2013. Aplikasi Analisis Multivariate dengan Program IBM SPSS 2.2. Edisi 7. Semarang: Badan Penerbit Universitas Diponegoro.

Gizaw, Million., Matewos Kebede., and Sujata Selvaraj. 2015. The Impact of Credit Risk on Profitability Performance of Commercial banks in Ethiopia. African Journal of Business Management, 9 (2), pp. 59-66.

Kasmir. 2010. Analisis Laporan Keuangan. Edisi ke 3. Jakarta: Rajawali Pers.

Kolapo, T funso. 2012. Credit Risk and Commercial Banks' Performance in Nigeria: A Panel Model Approach. Australian Journal of Business and Management research, 2 (2), pp. 31-38.

Kusnandar, E. 2012. Analisis Faktor-faktor yang mempengaruhi Pemberian Kredit UMKM oleh Perbankan di Indonesia. Tesis Pascasarjana Universitas Indonesia, Jakarta.

Kusuma, Harera Angga. 2014. Analisis Faktor-faktor yang mempengaruhi Penyaluran Kredit Usaha Rakyat (KUR) Periode 2009-2011. Skripsi Universitas Diponegoro, Semarang.

Leksana, Sonny. 2016. The Implementation of Kredit Usaha Rakyat Granting on Market Traders Who Are the Customers of Bank Rakyat Indonesia in Tawangalun Banyuwangi. Journal of Marketing and Consumer Research (An International Peer-reviewed Journal), 19 (1), pp. 63-69.

Oktaviani. 2012. Pengaruh DPK, ROA, CAR, NPL, dan Jumlah SBI terhadap Penyaluran Kredit Perbankan (Studi pada Bank Umum Go Publik di Indonesia Periode 2008-2011). Skripsi Sarjana Jurusan Management pada Fakultas Ekonomika dan Bisnis Universitas Diponegoro, Semarang. 
Ongroe, V. O., and Kusa G. B. 2013. Determinant of Financial performance of Commercial Banks in Kenya. International Journal of Economics and Financial Issue, 3 (1), pp. 237-252.

Prabowo, Anggono Yuda. 2014. Pengaruh Dana Pihak Ketiga (DPK), Capita; Adequacy Ratio, Non Performing Loan (NPL), terhadap Penyaluran Kredit Usaha Rakyat (KUR) Studi Kasus pada PT. Bank Manidiri (Persero) Tbk. Jurnal Ilmiah.

Purba, Novyanti Nora., Yusman Syaukat., dan Tb. Nur Ahmad Maulana. 2016. Faktor-faktor yang Mempengaruhi Tingkat Penyaluran Kredit pada BPR Konvensional di Indonesia. Jurnal Aplikasi Bisnis dan Manajemen, 2 (2), hal. 105-117.

Rahayu, Yoseva Maria Puji. 2012. Analisis Pengaruh capital Adequacy ratio, Return On Assets, Non Performing Loan, dan Suku Bunga SBI terhadap Jumlah Kredit yang disalurkan Bank, Jurnal Ilmiah.

Riduwan dan Kuncoro, Engkos Achmad. 2011. Cara Mengunakan dan Memakai Path Analysis (Analisis Jalur). Bandung: Alfabeta.

Rini, I K., and Sufian S. 2013. Analisis Pengaruh NPL, Proporsi dewan Komisaris Independen, BOPO, CAR, dan Ukurran Perusahaan terhadap Kinerja Keuangan. Diponegoro Journal of Management, 2 (2), hal. 1-12.

Sania, Zulcha Mintachus., dan Dewi Urip Wahyuni. 2016. Pengaruh DPK, NPL, dan CAR terhadap Jumlah Penyaluran Kredit Perbankan Persero. Jurnal Ilmu dan Riset Manajemen, 5 (1), hal. 1-15.

Serli. 2016. Pengaruh DPK, LDR, NPL, CAR, ROA, BOPO, Suku BUnga terhadap Penyaluran Kredit (Studi pada Industri Perbankan yang Terdaftar di Bursa Efek Indonesia Tahun 2010-2014). Skripsi Universitas Halu Oleo, Kendari.

Shingjergji, Ali., and Marsida Hyseni. 2015. The Determinant of Cpapital Adequacy Ratio in The Albanian Banking System During 2007-2014. International Journal of Economis, Commerce nd Management, 3 (3), pp. $1-10$.

Sudana, I Made. 2011. Manajemen Keuangan Perbankan, Teori dan Praktik. Jakarta: Erlangga.

Sukma, Yoli Lara. 2013. Pengaruh Dana Pihak Ketiga, Kecukupan Modal, Dan Risiko Kredit Terhadap Profitabilitas (Perusahaan Perbankan yang Terdaftar di BEI). Jurnal Fakultas Ekonomi Universitas Negeri Padang.

Wicaksono, Arief Prih. 2016. Pengaruh capital adequacy ratio, loan to deposit ratio, Non performing loan dan Biaya Operasional terhadap Profitabilitas Perusahaan Perbankan yang Terdaftar di bursa Efek Indonesia. Skripsi 
Sarjana Jurusan Manajemen pada Fakultas Ekonomika dan Bisnis Universitas Negeri Yogyakarta, Yogyakarta.

Widiyanti, H., dan Muchtar Mariso Sjahruddin, MA. 2014. Analisis pengaruh CAR, ROA, NPL, BOPO dan DPK terhadap penyaluran kredit UMKM di Indonesia (Studi pada bank umum yang terdaftar di BEI periode 20102012). JOM FEKON, 1 (2).pp. hal. 1-15.

www.bi.go.id

www.bri.co.id

Yatningsih, Nur Fakhri., dan Mochammad Chabachi. 2015. Analisis pengaruh BOPO, LDR, NPL, SIZE, CAR dan NIM terhadap ROA (studi pada bank umum konvensional yang listing di bursa efek Indonesia Periode 20092013). Diponegoro Journal of Management, 4(3), hal. 1-10. 